\title{
The draTG gene region of Rhodobacter capsulatus is required for post-translational regulation of both the molybdenum and the alternative nitrogenase
}

\author{
BERND MASEPOHL, ReINER KREY and WerNER KLIPP* \\ Lehrstuhl für Genetik, Fakultät für Biologie, Universität Bielefeld, D-33501 Bielefeld, Germany
}

(Received 8 April 1993; revised 24 April 1993; accepted 10 June 1993)

\begin{abstract}
Synthetic oligonucleotides, which were designed according to amino acid sequences conserved between Rhodospirillum rubrum and Azospirillum brasilense DraT and DraG, respectively, were used to identify the corresponding genes of Rhodobacter capsulatus. Sequence analysis of a $1904 \mathrm{bp}$ DNA fragment proved the existence of $R$. capsulatus draT and draG. These two genes were separated by 11 bp only, suggesting that $R$. capsulatus draT and draG were part of one transcriptional unit. In contrast to $R$. rubrum, $A$. brasilense and Azospirillum lipoferum, the $R$. capsulatus draTG genes were not located upstream of the structural genes of nitrogenase nifHDK but close to the $\operatorname{dct} P$ gene at a distance of about $1000 \mathrm{~kb}$ from the nifHDK genes. Deletion mutations in the draTG gene region were constructed and introduced into $R$. capsulatus wild-type and a nifHDK deletion strain. The resulting mutant strains were examined for post-translational regulation of the molybdenum and the alternative nitrogenase in response to ammonia and darkness. Under 'switch-off' conditions the modified (ADP-ribosylated) and the non-modified forms of component II of both the molybdenum and the alternative nitrogenase were detected in a draTG wild-type background by immunoblot analysis, whereas only the nonmodified forms were present in the draTG deletion strains. Nitrogenase activity in these strains was followed by the acetylene reduction assay. In contrast to the wild-type, draTG mutants were not affected in nitrogenase activity in response to ammonia or darkness. These results demonstrated that the draTG genes are required for posttranslational regulation of both the molybdenum and the heterometal-free nitrogenase in $\boldsymbol{R}$. capsulatus.
\end{abstract}

\section{Introduction}

In the process of biological nitrogen fixation atmospheric dinitrogen is converted into ammonia by the nitrogenase enzyme complex which consists of two components: dinitrogenase (component I or MoFe protein encoded by nifDK) and dinitrogenase reductase (component II or Fe protein encoded by nifH). Since this process is very energy-demanding, nitrogenase activity is highly regulated. Regulation occurs at the transcriptional level by the $n t r$-system and the regulatory nif $A$ gene which is present in all nitrogen fixing bacteria, except cyanobacteria, analysed so far (Gussin et al., 1986; Kranz \& Foster-Hartnett, 1990; Hennecke, 1990).

*Author for correspondence. Tel. +49521 1062034 ; fax +49521 1065626.

The EMBL accession number for the sequence reported in this paper is $\mathrm{X} 71131$.
In addition to the transcriptional regulation of nif gene expression, some bacteria contain a post-translational regulatory system, which causes rapid inhibition ('switch-off') of nitrogenase component II (Zumft \& Castillo, 1978; Pope et al., 1985; Jouanneau et al., 1989; Fu et al., 1990b; Liang et al., 1991; Zhang et al., 1992). Post-translational regulation of nitrogenase activity is best-characterized in Rhodospirillum rubrum (Pope et al., 1985; Lowery et al., 1986; Saari et al., 1986; Lowery \& Ludden, 1988; Liang et al., 1991). Inactivation of nitrogenase reductase by ADP-ribosylation is catalysed by the $d r a T$ gene product (dinitrogenase reductase ADPribosyltransferase) in response to ammonia, oxygen or darkness. The reverse reaction restoring nitrogenase activity is catalysed by the DraG protein (dinitrogenase reductase-activating glycohydrolase).

The target for ADP-ribosylation is the arginine residue at position 101 (with regard to $R$. rubrum NifH; Pope et al., 1985). An Arg-101-Val mutation prevented ADPribosylation of the $R$. rubrum mutant $\mathrm{NifH}$ protein but 
Table 1. Bacterial strains and plasmids

\begin{tabular}{|c|c|c|}
\hline Designation & Relevant characteristics & Reference \\
\hline \multicolumn{3}{|l|}{ Bacterial strains } \\
\hline $\begin{array}{l}\text { Rhodobacter capsulatus B10S } \\
\text { Rhodobacter capsulatus KS36 }\end{array}$ & $\begin{array}{l}\text { Spontaneous } \mathrm{Sm}^{\mathrm{r}} \text { mutant of } R \text {. capsulatus } \mathrm{B} 10 \\
\text { nifHDK deletion derivative of } R \text {. capsulatus } \\
\mathrm{B} 10 \mathrm{~S}, \mathrm{Sp}^{\mathrm{r}}\end{array}$ & $\begin{array}{l}\text { Klipp et al. (1988) } \\
\text { K. Schüddekopf (Bielefeld) }\end{array}$ \\
\hline Rhodobacter capsulatus W107I/II & $\begin{array}{l}\text { draTG deletion derivatives of } R \text {. capsulatus } \\
\text { B10S, } \mathrm{Gm}^{\mathrm{r}}\end{array}$ & This study \\
\hline Rhodobacter capsulatus KS36-W107I/II & $\begin{array}{l}\text { draTG deletion derivatives of } R \text {. capsulatus } \\
\text { KS } 36\end{array}$ & This study \\
\hline Escherichia coli JM83 & Host for pUC8 and pSVB plasmids & Vieira \& Messing (1982) \\
\hline Escherichia coli $\mathrm{S} 17-1$ & $\begin{array}{l}\text { RP4-2 (Tc::Mu) }(\mathrm{Km}:: \mathrm{Tn} 7) \text { integrated in the } \\
\text { chromosome }\end{array}$ & Simon et al. (1983) \\
\hline \multicolumn{3}{|l|}{ Plasmids } \\
\hline pUC8 & $\mathrm{Ap}^{\mathrm{r}} \mathrm{Lac}^{+}$ & Vieira \& Messing (1982) \\
\hline pSVB plasmids & $\mathrm{Ap}^{\mathrm{r}} \mathrm{Lac}^{+}$ & Arnold \& Pühler (1988) \\
\hline pSUP301 & $\mathrm{Ap}^{\mathrm{r}} \mathrm{Km}^{\mathrm{r}} m o b$ & Simon et al. (1983) \\
\hline pBMW101 & $\begin{array}{l}7 \cdot 1 \mathrm{~kb} \text { HindIII fragment carrying } R \text {. capsulatus } \\
\text { draTG cloned into pUC8 }\end{array}$ & This study \\
\hline pBMW106I & $\begin{array}{l}5.5 \mathrm{~kb} \text { HindIII-BamHI fragment from } \\
\text { pBMW101 cloned into a pSUP } 301 \text { derivative } \\
\text { carrying the aphII gene of Tn } 5\end{array}$ & This study \\
\hline pBMW107I/II & $\mathrm{Gm}^{\mathrm{r}}$ deletion derivatives of $\mathrm{pBMW} 106 \mathrm{I}$ & This study \\
\hline
\end{tabular}

also eliminated nitrogenase activity (Lehman \& Roberts, $1991 \mathrm{~b}) . \mathrm{Arg}_{101}$ and adjacent amino acid residues are highly conserved between the $\mathrm{NifH}$ proteins from different organisms and a possible role of this residue for ionic interactions between component I and component II has been discussed for Azotobacter vinelandii (Wolle $e t$ al., 1992). The enteric nitrogen-fixing bacterium Klebsiella pneumoniae is devoid of a draTG-mediated regulatory mechanism. However, introducing the draTG genes from Azospirillum lipoferum or $R$. rubrum into $K$. pneumoniae enabled this organism to respond to ammonia with a reversible regulation of nitrogenase activity (Fu et al., 1990a). The target of ADP-ribosylation is not only conserved in dinitrogenase reductases of the 'conventional' molybdenum nitrogenase but also in the corresponding proteins of alternative nitrogen fixation systems (Robson et al., 1986; Joerger et al., 1989; Schüddekopf $e t$ al., 1993) and it has been shown that the alternative nitrogenase of $R$. rubrum is also modified by DraT (Lehman \& Roberts, 1991a).

The photosynthetic non-sulphur purple bacterium Rhodobacter capsulatus also contains two nitrogenase systems: the molybdenum nitrogenase (encoded by nifHDK) and an alternative heterometal-free ('irononly') nitrogenase (anfHDGK; Schneider et al., 1991b; Gollan et al., 1993; Schüddekopf et al., 1993). Only the molybdenum nitrogenase has been analysed for ADPribosylation (Jouanneau et al., 1989; Hallenbeck, 1992; Pierrard et al., 1993). Site-directed mutations changing $\mathrm{Arg}_{102}$ into tyrosine or phenylalanine resulted in partially active mutant $\mathrm{NifH}$ proteins which were no longer substrates for ADP-ribosylation (Pierrard et al., 1993). However, $R$. capsulatus strains containing these mutant proteins still showed a 'switch-off' response to ammonia. This result implied a second mechanism of ammonia regulation which might act either on ATP or electron supply of nitrogenase (Pierrard et al., 1993).

In the present study, we describe the identification and characterization of the $R$. capsulatus draTG genes. $R$. capsulatus strains carrying mutations in the draTG genes were constructed and analysed for post-translational regulation of both the molybdenum and the alternative nitrogenase.

\section{Methods}

Bacterial strains and plasmids. The bacterial strains and plasmids used in this study are listed in Table $1 . R$. capsulatus strains B10S, W107I and W107II were grown diazotrophically in RCV medium as described previously (Klipp et al., 1988; Masepohl et al., 1988, 1993; Moreno-Vivian et al., $1989 a, b$ ). To analyse the alternative nitrogenase, which is repressed by molybdenum, the $R$. capsulatus nifHDK deletion strains KS36, KS36-W107I and KS36-W107II were grown in molybdenum-deficient medium (Schneider et al., 1991a).

Hybridization and cloning procedures. Two degenerate oligonucleotides used as draT- (5'-GG[C/G]GC[G/C]GT[G/C]CT[G/C]AA[G/ A]GG[C/G]TGGGT[G/C]G-3') or draG-specific probes (5'-GG[C/ G]GG[C/G]GA[C/T]GC[C/G]GA[C/T]AC[C/G]AC[C/G]GG[C/ G]GC-3') were $3^{\prime}$ end-labelled (DIG oligonucleotide tailing kit, Boehringer Mannheim) and hybridization experiments were performed using the DIG luminescent detection kit for nucleic acids (Boehringer Mannheim). To isolate the $7 \cdot 1 \mathrm{~kb} H$ indIII fragment carrying the $R$. capsulatus draTG genes 120 clones of a size-fractionated HindIII gene bank were screened. Two clones containing the $7 \cdot 1 \mathrm{~kb}$ HindIII fragment were identified. A $5.5 \mathrm{~kb}$ HindIII-BamHI fragment was subcloned into 
a derivative of the mobilizable vector plasmid pSUP301 by standard methods (Sambrook et al, 1989). A DNA fragment carrying the gentamicin resistance gene $(\mathrm{Gm})$ from pPH1JI (Hirsch \& Beringer, 1984) was subsequently used to replace an internal 404 bp EcoRI fragment (Figs 1 and 2). The resulting hybrid plasmids pBMW107I and pBMW107II were mobilized from Escherichia coli S17-1 into $R$. capsulatus B10S and KS36, respectively, by filter matings (Masepohl et al., 1988). Marker rescue was followed by selection for gentamicin resistance and test for loss of the vector-encoded kanamycin resistance as described previously (Masepohl et al., 1988, 1993; Moreno-Vivian et $a l ., 1989 a, b)$.

DNA sequencing. Appropriate restriction fragments of plasmid pBMW101 were subcloned into different $\mathrm{pSVB}$ vector plasmids. DNA sequencing by the dideoxy method (Sanger et al., 1977) was performed using a commercial T7 polymerase sequencing kit (Pharmacia). In addition to the universal and reversal primers, two synthetic oligonucleotides (5'-CGCGCTGCTCGGGGTCGATG-3' and 5'-CGCCGGGTTTGCCGCCTGGC-3') were used.

Biochemical methods. $R$. capsulatus strains were grown diazotrophically in $3 \mathrm{ml}$ cultures in $15 \mathrm{ml}$ tubes under an atmosphere of pure nitrogen. In late exponential phase cultures the $d r a T$ gene product was activated by addition of ammonia to a final concentration of $7.5 \mathrm{~mm}$. Cell-free protein extracts of these cultures were prepared as described by Masepohl et al. (1988). SDS-PAGE was carried out according to Laemmli (1970), followed by immunoblots as described by Sambrook et al. (1989). Detection of component II of the molybdenum nitrogenase from $R$. capsulatus was performed using an antiserum against Azotobacter vinelandii component II (AvII; Dingler et al., 1988) whereas modification of component II of the alternative nitrogenase from $R$. capsulatus ( $\mathrm{RcII}^{*}$ ) was analysed with an antiserum against partially purified RcII*.

Nitrogenase assays in vivo. Nitrogenase activity was measured in whole cells by the acetylene reduction method in a Hewlett-Packard gas chromatograph model 5890 series II with a Chrompack alumina GC column for the acetylene/ethylene/ethane separation. A $1 \mathrm{ml}$ vol. of cells was withdrawn anaerobically from a $100 \mathrm{ml}$ culture vessel and injected into a $5 \mathrm{ml}$ stoppered serum vial flushed with argon. The vial was placed in an illuminated shaking water bath at $30^{\circ} \mathrm{C}$. The reaction was started by the addition of $0.25 \mathrm{ml}$ acetylene. After 1 or $2 \mathrm{~min}$, depending on the strain analysed, $100 \mu \mathrm{l}$ samples of the gas phase were taken and analysed by gas chromatographic methods.

\section{Results and Discussion}

\section{Identification and cloning of the $R$. capsulatus draTG genes}

Two amino acid sequences of DraT and DraG, respectively, conserved between Rhodospirillum rubrum (Fitzmaurice et al., 1989) and Azospirillum brasilense (Zhang et al., 1992) were chosen to design corresponding oligonucleotides on the basis of the $R$. capsulatus codon preference. These conserved regions within the DraT or DraG proteins are marked in Fig. 3. The oligonucleotides (see Methods) were used as hybridization probes to identify draTG homologous genes in $R$. capsulatus total DNA. Both probes hybridized with a $7 \cdot 1 \mathrm{~kb}$ HindIII fragment which was isolated from a size-fractionated HindIII gene bank. The physical map of this $7 \cdot 1 \mathrm{~kb}$ HindIII fragment is shown in Fig. 1(a). Detailed
Southern hybridization analyses revealed that the $d r a T$ specific probe hybridized to a $1.1 \mathrm{~kb}$ HindIII-EcoRI fragment, whereas the $d r a G$ homologous region was located on a $1.5 \mathrm{~kb}$ Pst I fragment.

\section{DNA sequence analysis of the $R$. capsulatus draTG gene region}

A 1904 bp DNA fragment hybridizing to draT- and draG-specific probes was subjected to DNA sequence analysis (Fig. $1 b$ ) and the complete nucleotide sequence is presented in Fig. 2. Two open reading frames were identified. Assignment of these ORFs as $R$. capsulatus $d r a T$ and $d r a G$ was based on deduced amino acid sequence identity to dra gene products from $R$. rubrum (Fitzmaurice et al., 1989) and A. brasilense (Zhang et al., 1992). A comparison of the predicted DraT and DraG protein sequences of $R$. capsulatus, $R$, rubrum and $A$. brasilense is given in Fig. 3 . The $R$. capsulatus draT gene product showed an overall identity of $39 \%$ to the $A$. brasilense and $47 \%$ to the $R$. rubrum DraT protein. An even higher degree of identity was found for the DraG proteins. About $54 \%$ and $62 \%$ of the amino acids of $R$. capsulatus DraG are identical to the DraG proteins of $A$. brasilense and $R$. rubrum, respectively. Although both DraT and DraG interact with the same substrates (component II of nitrogenase and adenosine nucleotides), no similarities were found between the primary sequences of DraT and DraG.

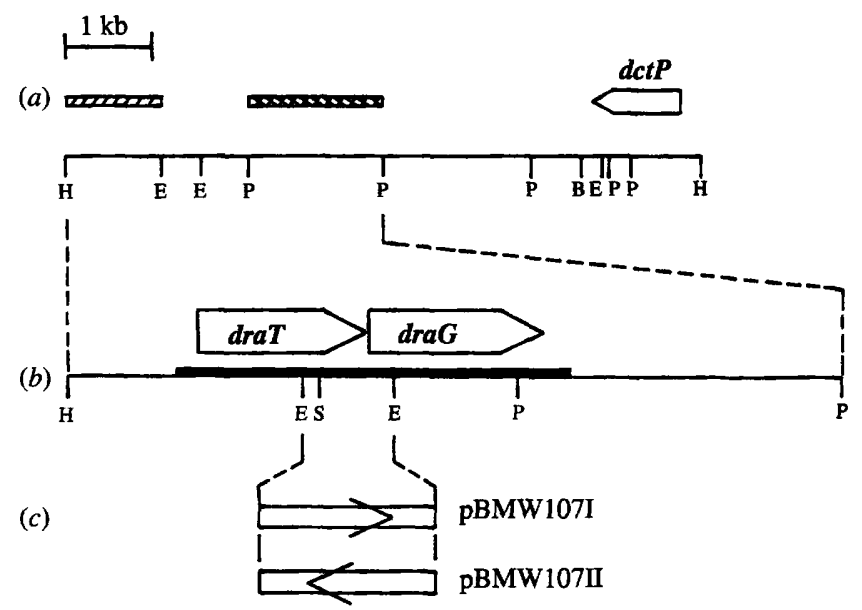

Fig. 1. Physical and genetic map of the $R$. capsulatus draTG gene region. DNA fragments hybridizing to $d r a T$ - and $d r a G$-specific probes are marked by hatched or cross-hatched bars, respectively, above the physical map of the $R$. capsulatus draTG gene region $(a)$. The location of $\operatorname{dct} P$ at the right-hand end of the map is based on partial DNA sequence analysis. The sequenced region carrying the $R$. capsulatus $d r a T$ and $d r a G$ genes is emphasized by a thick line (b). A 404 bp internal $E c o$ RI fragment was replaced by an interposon encoding gentamicin resistance resulting in hybrid plasmids pBMW107I and pBMW107II (c). The arrowheads indicate the orientation of the gentamicin resistance gene. The interposon is not drawn to scale. Abbreviations: B (BamHI); E (EcoRI); H (HindIII); P (PstI); S (SaII). 


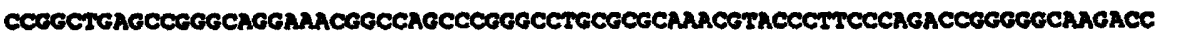

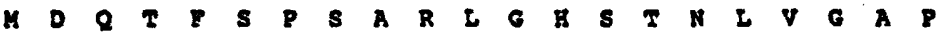
CCATCATCCGGCCATEGATCAAACCTTITCTCCTICCCCACGCCTTCOCCATTCCACCAATCTEGTCGGCGCGCC 250

DraT

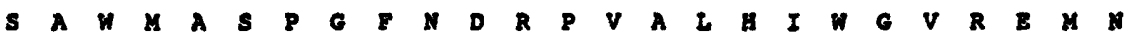
CrCGCCCTGGATGGCGAGCCCCGGCTTCAACGATCGGCCCOTTGCGCTGCATATCTGGGGCOTGCGGGAAATGAA

P A I I I I I

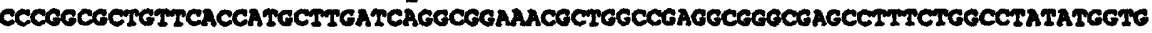

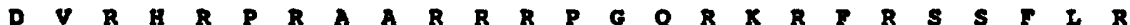
CGATGTYCGGCATCGACCCCGAGCAGCGCGACGCCGCCCCGGGCAGCGCAACCGOTTCCGCTCETCCTTCCTGCG 375

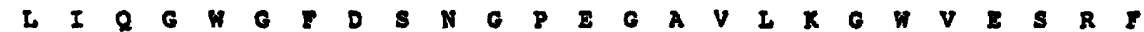
GCTCATTCAGGGCTGGGOTHTTGACAGCAACGGCCCCGAGGGCGCGGTGCTGAAGGOCTGGGTGGAAAGCCGCTI

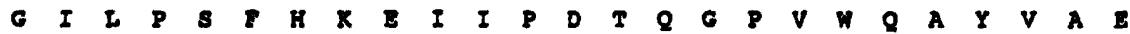
CEGCATCCTGCCCAGCTTTCACAAGGAGATCATCCCCGATACCCAGGGCCCGOTCRGGCAGCCCTATGTGGCCGA

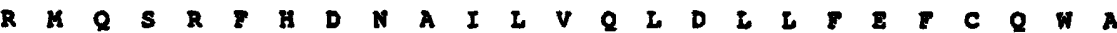
ACGGATECAAACCCGCTITCACGACAATGCOATCCTCGTGCAGCTCGATCTCCTGTTCGAATTCTGCCAATGGGC ECORI

$\begin{array}{lllllllllllllllllllllllll}V & A & V & S & P & I & R & G & K & A & S & D & A & I & S & R & H & O & C & G & R & P & A & W & H\end{array}$ GETECCCETTICGCCTATCCGGGGCAAAGCATCTGACGCTCTATCGCGGCATCAATGCGGTCGACCGGCATEGCA 600

$\begin{array}{lllllllllllllllllllllllll}S & G & I & A & X & P & P & R & V & I & R & L & N & N & L & V & S & F & S & S & D & R & E & V & A\end{array}$ TTCTGGAACAGCAAAGCCGCCGCGCGTAATCCGGCTCAACAATCTTETGTCGTTTTCCTCCGACCGCGAGCTGGC

$\begin{array}{lllllllllllllllllllllllll}D & C & E & G & D & R & I & I & I & I & R & V & P & I & A & K & V & L & E & F & P & G & I & I & P\end{array}$ GGACTGCTITGGCGACCGGATCATCACGACCCGGGTGCCGCTGGCCAAGGTGCTGTTCTTYCCCGGCCTGCTGCC

$\begin{array}{llllllllllllllllllllllll}S & P & I & I & R & G & E & R & E & F & L & V & I & G & G & A & F & R & V & S & I & E & D & I\end{array}$ CTCGCCCCTETTGCGGGGCOAGCGCGAATTTCTGOTCCTTGGCGGCGCGTTTCOGGTCAGTATCGAGGATATCTA

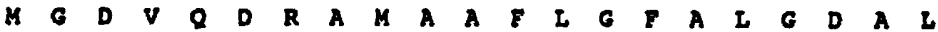
GGGGGATGCGCGATOGGCGATGTGCAGGATCGGGCGATGGCGGCCTTTCTCGGCTTLGCCCTGGGCGATGCGCTG 975

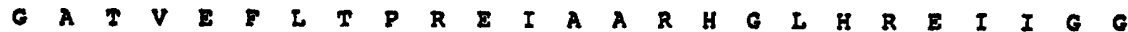
GGGGCGACGgTCGAATTCCTGACCCCGCGCGAGATCGCGGCGCGGCACGGCCTGCACAGGGAGATCATCGGCGGC 1050 ECORI

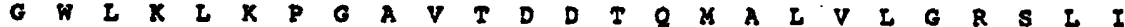
GCCTGGCTGAAGTTAAGCCCGGCGCGGTGACCGATGACACGCAGATGGCGCTGGTECTGGGGCGCTCGCTGATC 1125

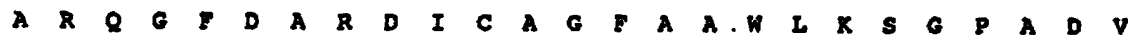
GCGCGGCAGGGCTTIGATGCAAGOGACATCTGCOCCGGGTTTCCCGCCTGGCTGAAATCGGGTCCGGCCGATGTC 1200

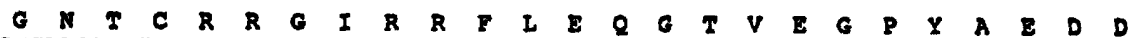
GGCAACACCTETCGGCGCGGCATCCGGCGGTTTTTGGAACAGGGCACGGTCGAGGGCCCCTATGCCGAGGATGAC 1275

$\begin{array}{lllllllllllllllllllllllll}A & G & \| & G & A & A & M & R & V & I & P & V & A & L & A & T & L & G & H & g & E & R & A & A & A\end{array}$ GCGGGCAATGGCGCGGCGATGCGGGTGCTGCCGOTGGCGCTGGCGACGCTGGGCCATCCCGAACGCGCCGCCGCC 1350

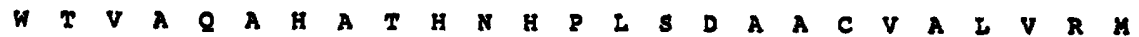
TEGACCGTGGCGCAGGCGCATGCOACGCATAACCACCCGCTCTCCGATGCCGCCTGTGTCGCGCTGGTGCGGATE 1425

$\begin{array}{lllllllllllllllllllllllll}V & O & G & L & V & I & G & G & G & A & A & V & I & A & R & E & A & E & R & I & I & A & O & H & R\end{array}$ GTGCAGGGGCTGGTECTTGGCGGGGGGGCCGCGGTCATTGCCCGCGAGGCCGAGCGGCTEATCGCGCAACATCGC 1500

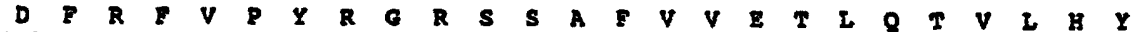
GATTTCCGTTTCGTCCCCTATCGCGGCCGOTCCTCGOCCTICGTEGTCGAGACGCTGCAGACGOTGCTGCATTAC 1575

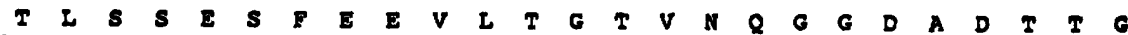
ACGCTCTCATCGGAGAGTTTCGAGGAGGTGCTGACCGGCACCGTCAATCAGGGCGGCGATGCCGATACGACGCGG 1650 A I A G M L A G A $R$ G G M A A I GCGCTGGCGGGGATGCTGGCGGGGGĆCCGCGCGGGATGGCGGCGCTGCCGGAACGCTGGCTTGCGGCGCTTEAC 1725

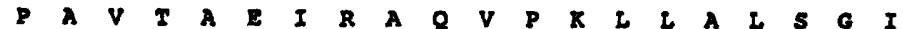
CCCGCGGTGACGGCCGAGATCCGCGCTCAGOTGCCGARGCTGCTGGCGCTTTCGGGCATCTGAGTGAGCTECCGG 1800 GCCAGATCGGCCTTGCGGGCAAGAAGCETCTCGGCCAGCGCCGCGCGCCGCCGAACCGGGCCACGACAATGCCGG 2875 ATTEGCCGCCCTCGGGCAGGCCGATACCA

Fig. 2. Complete nucleotide sequence of a DNA fragment containing the $R$. capsulatus draT and draG genes. The DNA sequence is presented in $5^{\prime}-3^{\prime}$ direction. The predicted amino acid sequences for two open reading frames (DraT and DraG) are indicated by the single letter code. A putative ribosomal binding site in front of $d r a G$ is marked by dots. The EcoRI sites used for construction of the draTG deletion mutants (Fig. $1 c$ ) are shown below the nucleotide sequence. 
DraT

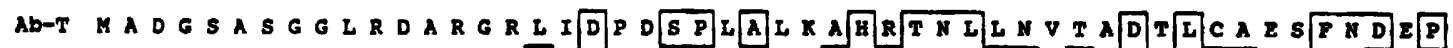
$R x-T$

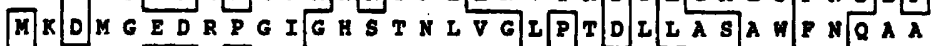
Re-T

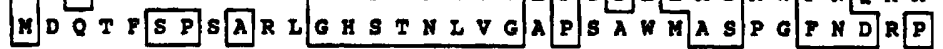

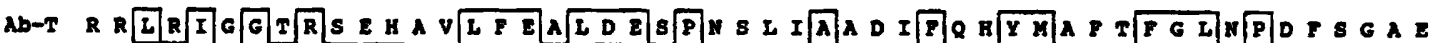

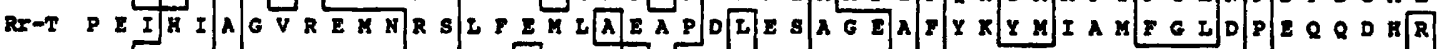
RC-T V A L H I W G V R E N N

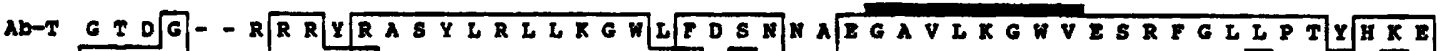

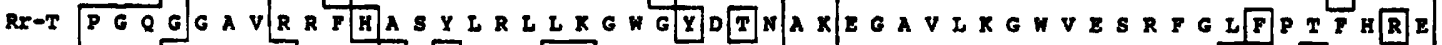

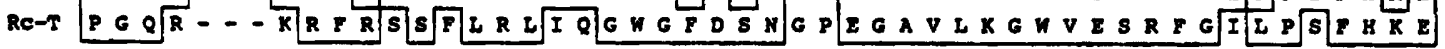
[SmeI]

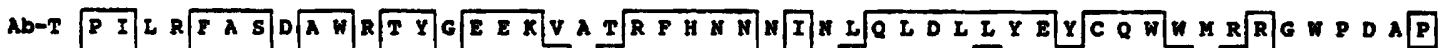

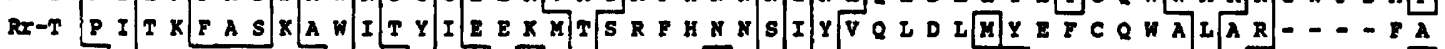

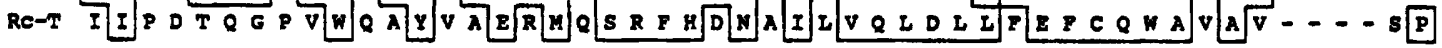
[ECORI]

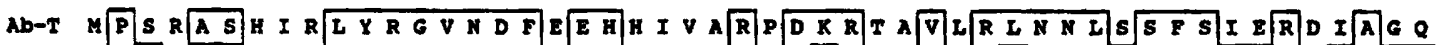

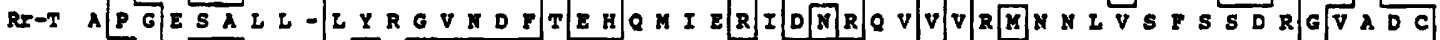

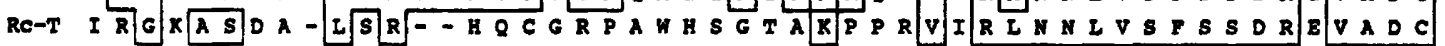
[Sa1I]

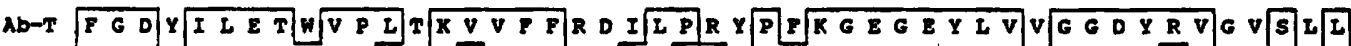

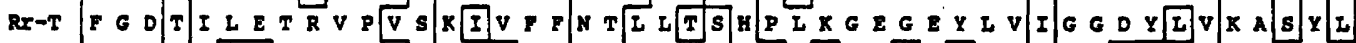

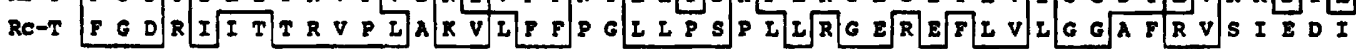
[SmeI]

DraG

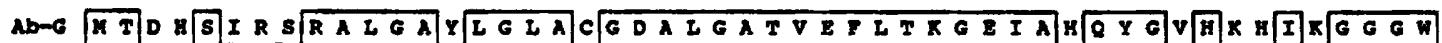

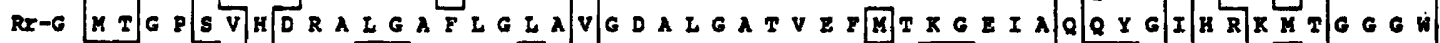

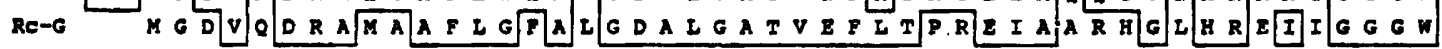
(ECORI)

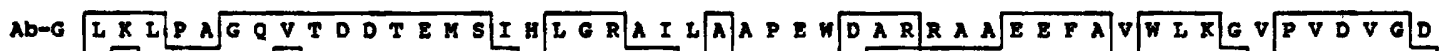

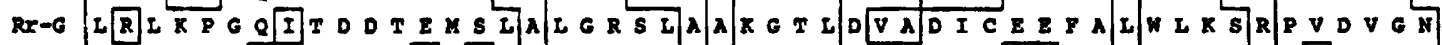

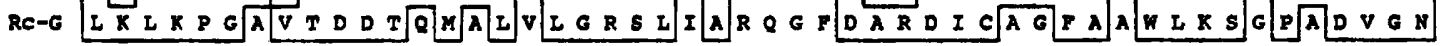

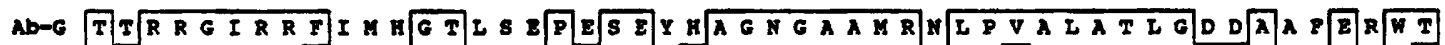

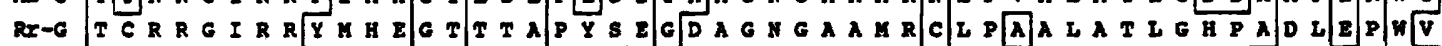

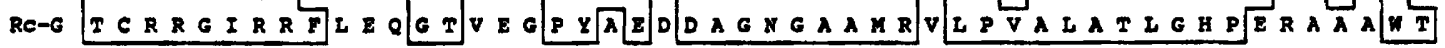

$A B-G$ VE

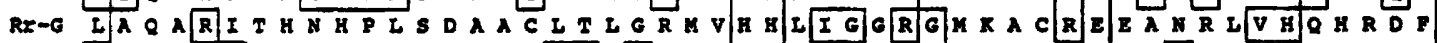

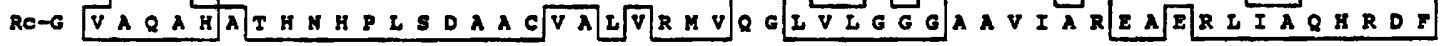

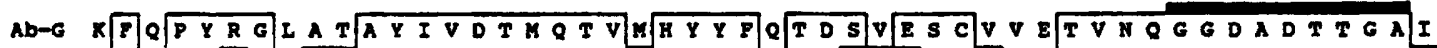

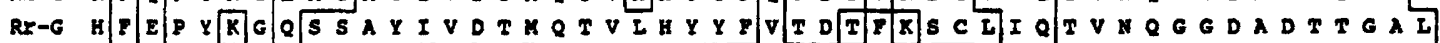

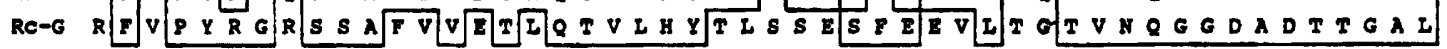
[PstI]

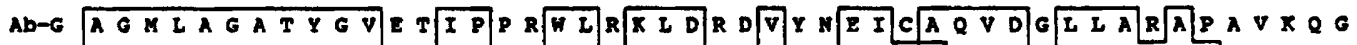

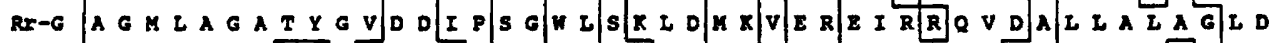

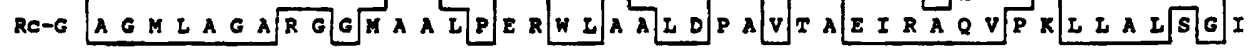

Fig. 3. Alignment of predicted amino acid sequences of DraT and DraG from Azospirillum brasilense (Ab), Rhodospirillum rubrum (Rr) and $R$. capsulatus $(\mathrm{Rc})$. The amino acid sequences are aligned for maximum matching and identical amino acid residues are boxed. Black bars indicate amino acid sequences conserved between $A$. brasilense and $R$. rubrum which served as templates to design draTand $d r a G$-specific oligonucleotide probes (see Methods). 


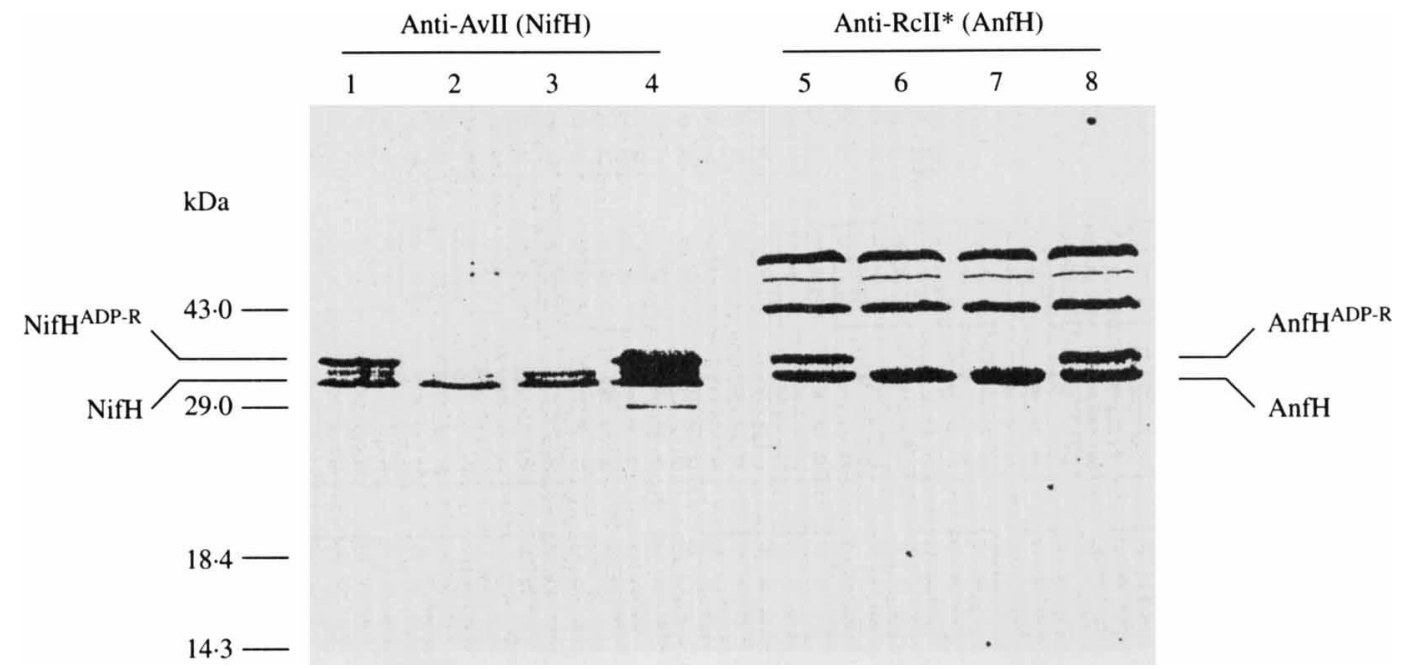

Fig. 4. Effect of ammonia on the modification of nitrogenase component II. $R$. capsulatus wild-type and mutant strains were grown diazotrophically as described in Methods. Prior to protein extraction ammonia was added to a final concentration of $7.5 \mathrm{mM}$. Proteins were separated by SDS-PAGE and component II of the molybdenum nitrogenase (NifH) and of the alternative nitrogenase (AnfH) were visualized by Western analysis using specific antisera. The original data from the Western analysis were digitally processed using a Hewlett-Packard Scan Jet II P. Lanes 1 and 4, R. capsulatus wild-type; lane 2, W107I (draTG::[ > Gm]), lane 3, W107II (draTG::[ < Gm]); lanes 5 and 8, R. capsulatus KS36 (nifHDK deletion strain); lane 6, KS36-W107I; lane 7, KS36-W107II.

The $R$. capsulatus $d r a T$ and $d r a G$ genes are separated by $11 \mathrm{bp}$, implying that they are co-transcribed. The likely initiation codon of the R. capsulatus $d r a T$ and $d r a G$ genes is ATG. A possible ribosome binding site (Stormo et al., 1982) is located in front of $d r a G$ whereas no typical Shine-Dalgarno sequence could be identified in front of draT.

The arrangement of the $R$. capsulatus draTG genes is the same as in $R$. rubrum (Fitzmaurice et al., 1989), $A$. brasilense (Zhang et al., 1992) and Azospirillum lipoferum (Fu et al., 1990b). However, no open reading frame homologous to the $15 \mathrm{kDa}$ ORF located downstream of $R$. rubrum and $A$. brasilense draG could be identified within the sequenced dra gene region from $R$. capsulatus. In contrast to $R$. rubrum, $A$. brasilense and $A$. lipoferum, the draTG genes of $R$. capsulatus are not located upstream of the structural genes of nitrogenase (nifHDK). However, partial DNA sequence analysis of adjacent DNA fragments (data not shown) and comparison of physical maps revealed that the $R$. capsulatus draTG genes are located close to the $d c t P$ gene (Fig. $1 a$; Shaw $e t$ $a l ., 1991)$. The $\operatorname{dct} P$ gene has previously been mapped at a distance of more than $1000 \mathrm{~kb}$ from the nifHDK genes (Fonstein et al., 1992).

\section{Mutational analysis of the $R$. capsulatus draTG genes}

To inactivate the $R$. capsulatus draTG genes, a $404 \mathrm{bp}$ EcoRI fragment encompassing the $3^{\prime}$ end of $d r a T$ and the $5^{\prime}$ end of $d r a G$ was replaced by a gentamicin resistance cassette (Fig. 1c). The gentamicin resistance interposon was previously shown to induce polar or non-polar mutations depending on the orientation (Moreno-Vivian et al., 1989 a; Masepohl et al., 1993). The hybrid plasmids pBMW107I and pBMW107II (Fig. 1c) carrying the interposon in both orientations were used to construct $R$. capsulatus draTG mutants. The draTG insertions were introduced into $R$. capsulatus wild-type resulting in mutant strains W107I and W107II, and into the nifHDK deletion strain KS36, which allows selective expression of the alternative nitrogenase (KS36-W107I and KS36W107II).

The influence of the draTG mutations on the posttranslational regulation of both the molybdenum and the heterometal-free nitrogenase was first examined by immunoblot analysis using sera containing antibodies against AvII or RcII*, respectively (Fig. 4). As expected, a cell-free protein extract of $R$. capsulatus wild-type prepared after activation of the draT gene product by ammonia contained two proteins representing the modified and the non-modified form of component II of the molybdenum nitrogenase. In contast, the $R$. capsulatus draTG mutant strains contained only the non-modified form of NifH. There was no difference between the $R$. capsulatus strains carrying the non-polar (W107I) or the polar draTG mutation (W107II). To analyse if the alternative nitrogenase of $R$. capsulatus was also subjected to ADP-ribosylation by DraT, similar experiments were performed for nifHDK deletion strains. In the parental nifHDK deletion strain KS36 two forms of component II of the alternative nitrogenase (AnfH) were detected after 'switch-off' by ammonia, whereas the nifHDK/draTG double mutants contained only the nonmodified form of AnfH (Fig. 4). These results indicated 

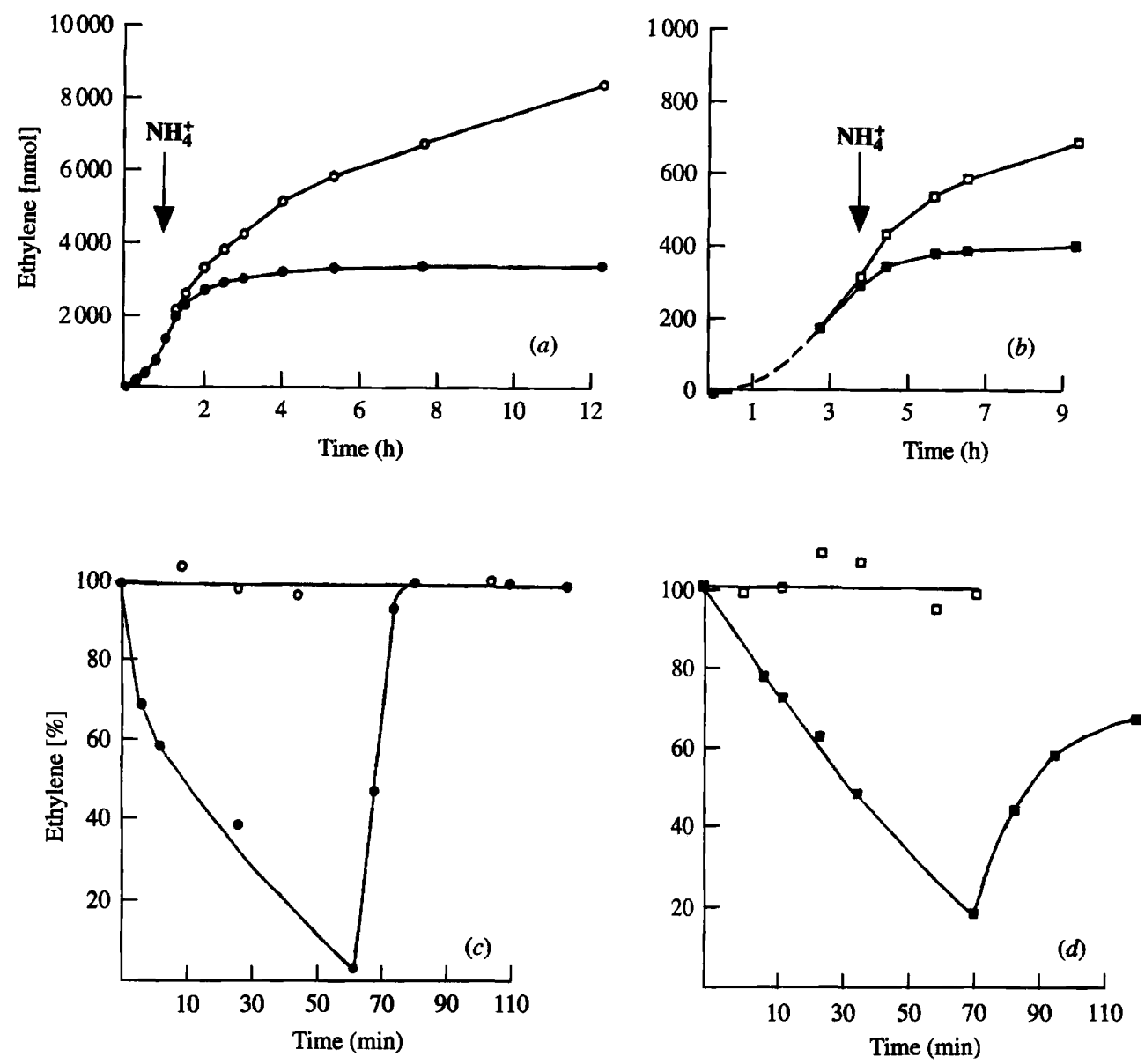

Dark

Light

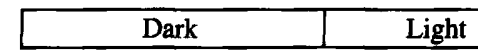

Fig. 5. Regulation of nitrogenase activity in response to ammonia and darkness. $R$. capsulatus wild-type and mutant strains were grown in $3 \mathrm{ml}$ cultures to an optical density of $1.5\left(\mathrm{OD}_{600}\right)$ in $15 \mathrm{ml}$ tubes under conditions expressing either the molybdenum $(a)$ or the alternative nitrogenase $(b)$ as described in Methods. At $t=0$, acetylene was added to a final concentration of $4 \%$ ( $/ \mathrm{v}$ ) in the gas phase and nitrogenase activity of these cultures was followed by measuring ethylene accumulation. At the indicated times, ammonia was added to a final concentration of $7.5 \mathrm{~mm}$. Symbols as defined for $(c)$ and $(d)$. To determine nitrogenase activity in response to darkness the same strains expressing the molybdenum $(c)$ or the alternative nitrogenase $(d)$ were grown in $100 \mathrm{ml}$ vessels and $1 \mathrm{ml}\left(O D_{600}=1 \cdot 5\right)$ aliquots were withdrawn for the acetylene reduction assay. Each sample was incubated at $30^{\circ} \mathrm{C}$ in the light and measured for activity after $1 \mathrm{~min}$ (for Mo nitrogenase containing strains) or $2 \mathrm{~min}$ (for Fe nitrogenase containing strains). $100 \%$ activity corresponds to 3240 (wild-type, O), 3500 (draTG deletion strain W107I, O), 171 (nifHDK deletion strain KS36, $\mathbf{)}$ ) and 212 (nifHDK/draTG double deletion strain $\mathrm{KS} 36-\mathrm{W} 107 \mathrm{I}, \square) \mathrm{nmol}$ ethylene produced $\mathrm{h}^{-1} \mathrm{ml}^{-1}$. All experiments shown in this figure were repeated twice.

that the draTG genes were required for ADP-ribosylation in response to addition of ammonia of both the molybdenum and the alternative nitrogenase in $R$. capsulatus.

Expression of the alternative nitrogenase in $R$. capsulatus is repressed by molybdenum (Schneider et al., $1991 a, b)$. To test the influence of molybdenum on posttranslational regulation, the $R$. capsulatus nifHDK deletion strain KS36 was derepressed for the alternative nitrogenase and molybdenum was added to a final concentration of $3 \mu \mathrm{M}$. However, molybdenum did not cause 'switch-off' of the alternative nitrogenase (data not shown), implying that the DraT protein was not activated by molybdenum.
Post-translational regulation of nitrogenase activities were followed under 'switch-off' conditions in response to ammonia by the acetylene reduction assay. In contrast to the parental strains, neither the molybdenum nor the heterometal-free nitrogenase were inactivated in response to ammonia in a draTG mutant background (Fig. $5 a, b$ ). In addition, post-translational regulation of both nitrogenase systems was also analysed in response to darkness (Fig. $5 c, d$ ). After $60 \mathrm{~min}$ of incubation in the dark the molybdenum nitrogenase activity was reduced to less than $10 \%$ in the wild-type, whereas no significant decrease in activity was found for the draTG mutant strain. Compared to $R$. rubrum (Liang et al., 1991), the inactivation of the molybdenum nitrogenase from $R$. 
capsulatus by darkness was almost complete but slower (40 $\mathrm{min}$ versus $60 \mathrm{~min}$ ). In contrast, recovery of nitrogenase activity in the light was very rapid and corresponded in this aspect to $R$. rubrum. Inactivation of the alternative nitrogenase in response to darkness was even slower than for the molybdenum nitrogenase. In contrast to the molybdenum nitrogenase, activity of the heterometal-free nitrogenase could not be recovered completely by light (Fig. $5 d$ ). This result indicated that (i) the modified form of AnfH was less stable than the ADPribosylated NifH protein, (ii) hydrolysis of the ADPribosylated form of AnfH could not be achieved completely by DraG, or (iii) component I of the alternative nitrogenase was more labile than the FeMo protein under 'switch-off' conditions. However, activity of the alternative nitrogenase was not influenced in the draTG mutant by darkness for at least 70 min making this strain particularly useful for the isolation of the alternative nitrogenase.

The authors thank S. Selsemeier for analysing nitrogenase activities in $R$. capsulatus draTG mutants, $\mathbf{K}$. Schneider for providing an antiserum against component II of the alternative nitrogenase from $R$. capsulatus, J. Oelze for providing an antiserum against $A$. vinelandii molybdenum nitrogenase component II, K.-U. Riedel for performing immunoblot analysis, and J. Pierrard for providing unpublished results. This work was supported by a grant from Bundesministerium für Forschung und Technologie (0319342A).

\section{References}

ArNold, W. \& Pühler, A. (1988). A family of high-copy-number plasmid vectors with single end-label sites for rapid nucleotide sequencing. Gene 70, 171-179.

Dingler, C., Kuhla, J., Wassink, H. \& Oelze, J. (1988). Levels and activities of nitrogenase proteins in Azotobacter vinelandii grown at different dissolved oxygen concentrations. Journal of Bacteriology 170, 2148-2152.

Fitzmaurice, W. P., SAari, L. L., Lowery, R. G., Ludden, P. W. \& ROBERTS, G. P. (1989). Genes coding for the reversible ADPribosylation system of dinitrogenase reductase from Rhodospirillum rubrum. Molecular and General Genetics 218, 340-347.

FonsteIn, M., ZHENG, S. \& HASELKORN, R. (1992). Physical map of the genome of Rhodobacter capsulatus SB 1003. Journal of Bacteriology 174, 4070-4077.

Fu, H., Burris, R. H. \& Roberts, G. P. (1990a). Reversible ADPribosylation is demonstrated to be a regulatory mechanism in prokaryotes by heterologous expression. Proceedings of the National Academy of Sciences of the United States of America 87, 1720-1724.

Fu, H.-A., Fitzmaurice, W. P., Roberts, G. P. \& Burris, R. H. $(1990 \mathrm{~b})$. Cloning and expression of draTG genes from Azospirillum lipoferum. Gene 86, 95-98.

Gollan, U., SCHNEIDER, K., MÜlLER, A., SCHÜdDEKopf, K. \& KLIPP, W. (1993). Detection of the in vivo incorporation of a metal cluster into a protein: the FeMo cofactor is inserted into the $\mathrm{FeFe}$ protein of the alternative nitrogenase of Rhodobacter capsulatus. European Journal of Biochemistry 215, 25-35.

Gussin, G. N., Ronson, C. W. \& Ausubel, F. M. (1986). Regulation of nitrogen fixation genes. Annual Reviews of Genetics 20, 567-591.

HALLENBECK, P. C. (1992). Mutations affecting nitrogenase switch-off in Rhodobacter capsulatus. Biochimica et Biophysica Acta 1118, 161-168.

HENNECKE, H. (1990). Nitrogen fixation genes involved in the Bradyrhizobium japonicum-soybean symbiosis. FEBS Letters 268 , 422-426.
HIRSCH, P. R. \& BERINGER, J. E. (1984). A physical map of pPH1JI and pJB4JI. Plasmid 12, 139-141.

Jokrger, R. D., Jacobson, M. R., Premakumar, R., Wolfinger, E. D. \& Bishop, P. E. (1989). Nucleotide sequence and mutational analysis of the structural genes (anfHDGK) for the second alternative nitrogenase from Azotobacter vinelandii. Journal of Bacteriology 171, $1075-1086$.

Jouanneau, Y., Roby, C., Meyer, C. M. \& Vignais, P. M. (1989). ADP-ribosylation of dinitrogenase reductase in Rhodobacter capsulatus. Biochemistry 28, 6524-6530.

KlIPP, W., MasePOHL, B. \& PÜHLER, A. (1988). Identification and mapping of nitrogen fixation genes of Rhodobacter capsulatus: duplication of a nifA-nifB region. Journal of Bacteriology 170, 693-699.

Kranz, R. G. \& Foster-HartnetT, D. (1990). Transcriptional regulatory cascade of nitrogen-fixation genes in anoxygenic photosynthetic bacteria: oxygen- and nitrogen-responsive factors. $\mathrm{Mol}$ ecular Microbiology 4, 1793-1800.

LAEMMLI, U. K. (1970). Cleavage of structural proteins during the assembly of the head of bacteriophage T4. Nature, London 227 , 680-685.

Lehman, L. J. \& RoberTs, G. P. (1991a). Identification of an alternative nitrogenase system in Rhodospirillum rubrum. Journal of Bacteriology 173, 5705-5711.

Lehman, L. J. \& RoberTs, G. P. $(1991 b)$. Glycine 100 in the dinitrogenase reductase of Rhodospirillum rubrum is required for nitrogen fixation but not for ADP-ribosylation. Journal of Bacteriology 173, 6159-6161.

Liang, J., Nielsen, G. M., Lies, D. P., Burris, R. H., Roberts, G. P. \& LUDDEN, P. W. (1991). Mutations in the draT and draG genes of Rhodospirillum rubrum result in loss of regulation of nitrogenase by reversible ADP-ribosylation. Journal of Bacteriology 173, 6903-6909.

LOWERY, R. G., SAARI, L. L. \& LUDDEN, P. W. (1986). Reversible regulation of the nitrogenase iron protein from Rhodospirillum rubrum by ADP-ribosylation in vitro. Journal of Bacteriology 166, 513-518.

LOWERY, R. G. \& LUDDEN, P. W. (1988). Purification and properties of dinitrogenase reductase ADP-ribosyltransferase from the photosynthetic bacterium Rhodospirillum rubrum. Journal of Biological Chemistry 263, 16714-16719.

MASEPOHL, B., KlIPP, W. \& PÜHLER, A. (1988). Genetic characterization and sequence analysis of the duplicated nif $A /$ nif $B$ gene region of Rhodobacter capsulatus. Molecular and General Genetics 212, 27-37.

MASEPOHL, B., ANGermüller, S., HenneCKe, S., HÜbNer, P., MoRenoVIVIAN, C. \& KLIPP, W. (1993). Nucleotide sequence and genetic analysis of the Rhodobacter capsulatus ORF6-nif $U_{\mathrm{I}} S V W$ gene region: possible role of NifW in homocitrate processing. Molecular and General Genetics 238, 369-382.

Moreno-Vivian, C., HenNecke, S., PüHLER, A. \& KLIPP, W. (1989a). Open reading frame 5 (ORF5), encoding a ferredoxinlike protein, and nifQ are cotranscribed with nifE, nif $N$, nif $X$, and ORF4 in Rhodobacter capsulatus. Journal of Bacteriology 171, 2591-2598.

Moreno-Vivian, C., Schmehl, M., Masepohl, B., ARnold, W. \& KuIPP, W. (1989b). DNA sequence and genetic analysis of the Rhodobacter capsulatus nifENX gene region: homology between NifX and NifB suggests involvement of NifX in processing of the iron-molybdenum cofactor. Molecular and General Genetics 216, 353-363.

Pierrard, J., Ludden, P. W. \& Roberts, G. P. (1993). Posttranslational regulation of nitrogenase in Rhodobacter capsulatus: existence of two independent regulatory effects of ammonium. Journal of Bacteriology 175, 1358-1366.

Pope, M. R., Murrell, S. A. \& Ludden, P. W. (1985). Covalent modification of the iron protein of nitrogenase from Rhodospirillum rubrum by adenosine diphosphoribosylation of a specific arginine residue. Proceedings of the National Academy of Sciences of the United States of America 82, 3173-3177.

RoBson, R., WoODLEY, P. \& JonEs, R. (1986). Second gene (nifH*) coding for a nitrogenase iron protein in Azotobacter chroococcum is adjacent to a gene coding for a ferredoxin-like protein. $E M B O$ Journal 5, 1159-1163. 
SAAri, L. L., Pope, M. R., Murrell, S. A. \& Ludden, P. W. (1986). Studies on the activating enzyme for iron protein of nitrogenase from Rhodospirillum rubrum. Journal of Biological Chemistry 261, 49734977.

Sambrook, J., Fritsch, E. F. \& Maniatis, T. (1989). Molecular Cloning. A Laboratory Manual. Cold Spring Harbor, NY: Cold Spring Harbor Laboratory.

SANGER, F., NiCKLEN, S. \& Coulson, A. R. (1977). DNA sequencing with chain-terminating inhibitors. Proceedings of the National Academy of Sciences of the United States of America 74, 5463-5467.

Schneider, K., Müller, A., Johannes, K.-U., DiemanN, E. \& KotTMANN, J. (1991a). Selective removal of molybdenum traces from growth media of $\mathrm{N}_{2}$-fixing bacteria. Analytical Biochemistry 193, 292-298.

SCHNeider, K., Müller, A., Schramm, U. \& KliPP, W. (1991 b). Demonstration of a molybdenum- and vanadium-independent nitrogenase in a nifHDK-deletion mutant of Rhodobacter capsulatus. European Journal of Biochemistry 195, 653-661.

SCHÜDDEKOPF, K., HENNECKE, S., LieSE, U., KUTSChE, M. \& KLIPP, W. (1993). Characterization of anf genes specific for the alternative nitrogenase and identification of nif genes required for both nitrogenases in Rhodobacter capsulatus. Molecular Microbiology 8, 673-684.
Shaw, J. G., Hambln, M. J. \& Kelly, D. J. (1991). Purification, characterization and nucleotide sequence of the periplasmic C4dicarboxylate-binding protein (DctP) from Rhodobacter capsulatus. Molecular Microbiology 5, 3055-3062.

Simon, R., Priefer, U. \& Pühler, A. (1983). A broad host range mobilization system for in vivo genetic engineering: transposon mutagenesis in Gram negative bacteria. Bio/Technology 1, 784-791.

Stormo, G. D., Schneider, T. D. \& Gold, L. M. (1982). Characterization of translational initiation sites in E. coli. Nucleic Acids Research 10, 2971-2996.

VIEIRA, J. \& Messing, J. (1982). The pUC plasmids, an M13mp7derived system for insertion mutagenesis and sequencing with synthetic universal primers. Gene 19, 259-268.

Wolle, D., Kim, C., Dean, D. \& Howard, J. B. (1992). Ionic interactions in the nitrogenase complex. Properties of Fe-protein containing substitutions for Arg-100. Journal of Biological Chemistry 267, 3667-3673.

ZhaNG, Y., BurRis, R. H. \& RoberTs, G. P. (1992). Cloning, sequencing, mutagenesis, and functional characterization of draT and draG genes from Azospirillum brasilense. Journal of Bacteriology 174, 3364-3369.

ZumfT, W. G. \& CASTILlo, F. (1978). Regulatory properties of the nitrogenase from Rhodopseudomonas palustris. Archives of Microbiology 117, 53-60. 